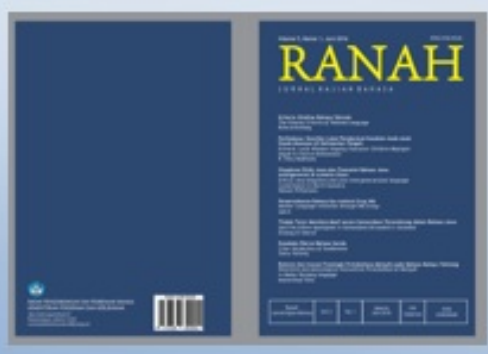

Ranah: Jurnal Kajian Bahasa

http://ojs.badanbahasa.kemdikbud.go.id/jurnal/index.php/jurnal_ranah

p-ISSN: $2338-8528$

e-ISSN: $2578-8111$

\title{
METAFORA PADA LAGU NYIDHAM SARI DAN YEN ING TAWANG ONO LINTANG
}

\author{
Metaphors on Song Nyidham Sari and Yen Ing Tawang Ono Lintang
}

\author{
Raditya Ranabumi \\ Universitas Sebelas Maret Surakarta \\ bumidito@gmail.com
}

Naskah Diterima Tanggal 14 Desember 2017-Direvisi Akhir Tanggal 20 November 2018—Disetujui Tanggal 1 Desember 2018 Doi https://doi.org/10.26499/rnh.v7i2.659

\begin{abstract}
Abstrak
Kajian metafora dalam semantik memang layak untuk diperbincangkan dalam dunia linguistik, bahasa-bahasa yang tidak lugas membuat banyak orang berfikir ulang untuk memahami suatu makna. Pada umumnya metafora itu adalah ungkapan kebahasaan untuk mengatakan sesuatu yang hidup untuk sesuatu lainnya yang hidup, yang hidup untuk sesuatu yang mati, sesuatu yang mati untuk hidup, dan sesuatu yang mati lainnya yang mati. Jika berbicara tentang lagu keroncong di Indonesia, hampir semua lagu bermakna lugas. Akan tetapi jika mengarah pada lagu Nyidam Sari dan Yen Ing Tawang Ono Lintang karya seniman Andjar Any tampaknya perlu dikaji lebih dalam karena dalam lirik-lirik yang disampaikan banyak sekali metafora yang tampak. Berdasarkan latar belakang tersebut, tujuan penelitian ini adalah memahami maknamakna yang tersirat dalam kedua lagu tersebut. Dalam penelitian ini peneliti menggunakan metode kualitatif deksriptif karena objek penelitian ini adalah lagu yang tertuang dalam teks. Kemudian, berdasarkan hasil penelitian yang sudah dilakukan dapat disimpulkan bahwa telah ditemukan 13 metafora dalam kedua lagu tersebut, yaitu 4 metafora nominatif, 4 metafora komplementatif, 4 metafora predikatif, dan 1 metafora kalimatif. Dengan demikian, terjawab sudah makna dari beberapa lirik lagu yang sebelumnya kurang dipahami masyarakat awam.
\end{abstract}

Kata Kunci: metafora, lagu, semantik

\section{Abstract}

The study of metaphors in semantics is indeed worth discussing in the world of linguistics, languages that are not straightforward make many people rethink to understand a meaning. In general, the metaphor is an expression of language to say something that lives for something else that lives, that lives for something that dies, something that dies for life, and something else that dies. When talking about keroncong songs in Indonesia, almost all songs mean straightforward. However, if it refers to the songs of Nyidam Sari and Yen Ing Tawang Ono Lintang, the work of artist Andjar Any seems to need to be studied more deeply because in the lyrics delivered there are a lot of visible metaphors. Based on this background, the purpose of this research is to understand the meanings implied in the two songs. In this study researchers used descriptive qualitative methods because the object of this research is the song contained in the text. Then, based on the results of the research that has been done, it can be concluded that 13 metaphors in both songs have been found, namely 4 nominative metaphors, 4 complementative metaphors, 4 predictive metaphors, and 1 calimative metaphors. Thus it has been answered that the meaning of some song lyrics was previously poorly understood by the general public.

Keywords: metaphor, song, semantic 
How to Cite: Ranabumi, Raditya. (2018). Metafora Pada Lagu Nyidham Sari dan Yen Ing Tawang Ono Lintang, Ranah: Jurnal Kajian Bahasa, 7 (2), 247-262. doi: https://doi.org/10.26499/rnh.v7i2.659

\section{PENDAHULUAN}

Kajian metafora dalam semantik memang layak untuk diperbincangkan dalam dunia linguistik, bahasa-bahasa yang tidak lugas membuat banyak orang berfikir ulang untuk memahami suatu makna. Padahal menurut Foriyani (2013) bahasa merupakan sarana komunikasi manusia dengan sesamanya dan juga untuk mengekspresikan buah pikirannya. Pada umumnya, metafora itu adalah ungkapan kebahasaan untuk mengatakan sesuatu yang hidup untuk sesuatu untuk sesuatu lainnya yang hidup, yang hidup untuk sesuatu yang mati, sesuatu yang mati untuk hidup, dan sesuatu yang mati lainnya yang mati.

Biasanya makna-makna metafora terdapat pada sebuah lagu atau puisi yang diciptakan oleh pengarang. Sebuah lagu yang pernah dianalisis dari sisi metafora sintaksisnya adalah lagu dari penyanyi terkenal dunia, yaitu Rihanna seperti yang dilakukan oleh Alicia (2017) dalam penelitian berjudul Analysis of Metaphors from Rihana's Songs. Berdasarkan penelitian tersebut banyak sekali makna metafora ditemukan dalam lirik lagunya yang terkadang kurang dipahami oleh masyarakat awam.

Jika berbicara tentang lagu keroncong di Indonesia, hampir semua lagu bermakna lugas. Penelitian yang berhubungan dengan karya tersebut pernah dilakukan oleh Ardiasta (2013) yang berjudul "Karakteristik Lagu Keroncong Karya Kusbini”. Hasil penelitian tersebut terbukti banyak sekali ditemukan karakteristik dan makna-makna metafora yang tersirat dalam lagu keroncong.

Akan tetapi, jika kita mengarah pada lagu Nyidam Sari dan Yen Ing Tawang Ono Lintang karya seniman Andjar Any tampaknya perlu dikaji lebih dalam karena dalam lirik-lirik yang disampaikan banyak sekali metafora yang tampak.

Menurut Subroto (2011: 115), pada dasarnya metafora merupakan gaya bahasa yang banyak digunakan dalam komunikaasi dengan bahasa. Metafora juga dapat dipandang sebagai bentuk kekreatifitasan pengguna bahasa karena metafora bahasa (C)2018, Ranah, 7 (2), 247-262 
sendiri timbul sebagai cara untuk mengatasi keterbatasan leksikon untuk membahasakan ide, objek, peristiwa, dan kualitas sesuatu. Di dalam karya sastra puisi, metafora banyak digunakan oleh pengarangnya dalam rangka mengekspresikan pikiran dan perasaannya. Selain itu, menurut Liwoso (2012: 15), metafora ialah suatu fenomena dengan perbandingan yang berbeda antara beberapa maksud. Hal ini adalah kondensasi beberapa bagian, seperti topik atau penanda dengan makna konotatif.

Metafora sering diartikan sebatas majas (gaya bahasa) perbandingan atas dasar persamaan. Namun, pada kenyataannya metafora sangat luas artinya. Menurut Subroto (2011: 24) ada metafora hidup dan ada metafora mati. Dari pengertian-pengertian tersebut, metafora perlu dikaji serta makna yang terkandung didalamnya.

Perubahan makna dalam kajian metafora juga terdapat pada lagu Nyidham Sari (NS) dan lagu Yen Ing Tawang Ono Lintang (YITW). Kedua lagu ini sebenarnya lagu yang berbeda, namun masih dalam satu tema. Namun, setelah ditelusuri kedua lagu ini memiliki maksud yang sama, meskipun beda lirik dan beda judul. Di sisi lain, lagu ini merupakan lagu yang menggunakan bahasa daerah, yaitu bahasa jawa. Menurut Kholidah (2015: 106), bahasa Jawa memiliki fungsi tersendiri sebagai identitas dan jati diri sebagai orang Jawa agar tidak kehilangan jawanya. Dapat disimpulkan bahwa kedua lagu ini mewakili perasaan orang Jawa serta menjelaskan pandangan orang Jawa dalam menghadapi suatu permasalahan terutama masalah asmara.

Dari latar belakang tersebut, penelitian ini bertujuan untuk mengkaji maknamakna metafora yang terkandung di dalam lagu NS dan lagu YITW beserta jenis-jenis metafora yang juga terdapat di dalam kedua lagu tersebut. Seperti yang telah diketahui, lagu-lagu yang diciptakan Andjar Any tidak jauh dari ungkapan kasih cintanya pada istri yang sangat ia cintai, yaitu "Piyatni", kebanyakan lagu ciptaan Andjar Any memang didedikasikan untuk sang istri.

\section{LANDASAN TEORI}

Metafora memiliki dua pengertian, yaitu metafora dalam arti luas dan metafora dalam arti sempit. Menurut Moeliono (2012), metafora adalah majas yang terbentuk dari kata serapan bahasa Arab kemudian diadaptasi ke dalam bahasa Indonesia menjadi 
majas, sedangkan metafora dalam arti sempit, yaitu bentuk kiasan tertentu di antara bentuk kiasan yang lain, yaitu metonimi, sinekdoke, dan hiperbola.

Secara mendasar metafora memang selalu dikategorikan ke dalam majas perbandingan. Secara meluas mengenai perbandingan dalam metafora Quintilian (dalam Wahab, 2010: 72) mengatakan bahwa metafora itu adalah ungkapan kebahasaan untuk mengatakan sesuatu yang hidup untuk sesuatu untuk sesuatu lainnya yang hidup, yang hidup untuk sesuatu yang mati, sesuatu yang mati untuk hidup, dan sesuatu yang mati lainnya yang mati. Namun, Wahab (2010: 72) mengartikan dalam arti yang lebih longgar. Ia tidak berpatokan pada sebatas majas perbandingan saja, namun ia juga memandang metafora dilihat dari tatanan sintaksisnya.

Secara sintaksis, menurut Wahab (2010: 72), membagi metafora menjadi tiga kelompok, yaitu:

1. Metafora Nominatif, Metafora ini menggunakan lambang kias hanya pada nomina kalimatnya saja. Bisa nomina yang berupa objek atau subjek kalimat. Karena posisi nomina itu berbeda-beda, Wahab (2010: 72) membagi lagi metafora nominatif menjadi dua kelompok, yaitu (1) metafora nominatif subjektif dan (2) metafora objektif. Namun, dua pembagian itu sering disebut sebagai metafora nominatif dan metafora komplementatif. Di dalam metafora nominatif lambang kias hanya pada subjek kalimat saja, yaitu nomina yang berfungsi menjadi subjek. Kedua, metafora komlementatif memakai lambang kias hanya pada komplemen kalimat dimaksud. Komplemen di sini merupakan nomina yang berfungsi sebagai komplemen atau pelengkap. Komponen lain dalam kalimat tetap dinyatakan dengan kata yang mempunyai kandungan makna langsung.

2. Metafora Predikatif, Metafora predikatif menggunakan lambang kias hanya pada predikanya saja, sedangkan subjek dan komponen lain dalam kalimat itu (jika ada) masih dinyatakan dalam makna langsung.

3. Metafora Kalimatif, Di dalam metafora kalimatif seluruh lambang kias yang dipakai dalam metafora ini tidak terbatas pada nomina (baik yang berfungsi sebagai subjek maupun yang berfungsi sebagai komplemen) dan predikatnya saja. Akan tetapi, seluruh komponen kalimat itu merupakan metafora. 


\section{METODE PENELITIAN}

Jenis penelitian ini termasuk penelitian kualitatif deskriptif. Kualitatif ialah penelitian yang bermaksud untuk memahami fenomena yang dialami oleh subjek penelitian secara holistik dan dengan cara deskripsi dalam bentuk kata-kata dan bahasa, pada suatu konteks hubungan khusus yang alamiah dan dengan memanfaatkan berbagai metode alamiah (Moleong, 2010:6). Jenis penelitian kualitatif deskriptif karena data yang dianalisis dan dihasilkan berupa kata-kata dan kalimat, bukan angka.

Objek penelitian ini adalah penggunaan metafora dari lirik lagu Nyidham Sari dan Yen Ing Tawang Ono Lintang karya Andjar Any. Data dan sumber data yang digunakan dalam penelitian ini berupa dokumen atau buku yang berisikan teks dalam lirik lagu Nyidham Sari dan Yen Ing Tawang Ono Lintang karya Andjar Any (2007: 34-36).

\section{PEMBAHASAN}

\section{Metafora dan Klasifikasinya}

a) Lagu 1 (Nyidham Sari)

\section{Bait 1}

Umpomo sliramu sekar melati (baris $1 /$ bait $1 /$ kalimat 1 ) Aku kumbang nyidam sari (baris $2 /$ bait $1 /$ kalimat2) Umpomo sliramu margi wong manis (baris $3 /$ bait $1 /$ kalimat 3 )

Aku kang bakal ngliwati (baris $4 /$ bait $1 /$ kalimat4)

Sinaksen lintange luku semono (baris $5 /$ bait $1 /$ kalimat 4 ) Janji prasetyaning ati Tansah kumanthel ning netro rinoso (baris $6 /$ bait $1 /$ kalimat 4 ) Roso rasaning driyo (baris $7 /$ bait $1 /$ kalimat5) (baris $8 /$ bait $1 /$ kalimat5)

Pada bait pertama dalam lagu Nyidham Sari ditemukan 6 bentuk metafora.

Metafora nominatif ditemukan pada larik berikut ini:

Umpomo sliramu [sekar melati] (baris 1/bait 1/kalimat1)

[Sekar melati] adalah bentuk metafora komplementatif karena kedudukannya sebagai komplemen atau pelengkap di dalam kalimat. Sekar melati, yang berarti bunga melati yang mengandaikan seseorang yang dipuja diandaikan sebagai bunga melati karena bunga melati termasuk kategori bunga yang indah. Pengarang mencoba memperlihatkan seseorang yang ia puja jika diukur dari bunga, 
layaknya bunga melati. Di dalam definisi menurut Quintilian (dalam Wahab, 2010: 72), bahwa metafora adalah ungkapan kebahasaan yang menyatakan benda mati untuk sesuatu yang hidup, [sekar melati] merupakan seseorang yang dipuja oleh pengarang.

\section{Aku [kumbang] nyidam sari}

(baris 2/bait 1/kalimat 2)

Larik di atas adalah lirik yang masih berkesinambungan dengan lirik pada baris pertama tadi. Di sini kata [kumbang] juga masih berfungsi sebagai subjek kalimat. Dengan begitu metafora ini tergolong metafora nominatif. Subjek [kumbang] yang berarti hewan kumbang, hewan yang sangat akrab dengan bunga, bunga yang dimaksud adalah ''bunga melati', Jadi, pengarang mendefinisikan dirinya sebagai hewan kumbang yang sangat mengidam-idamkan sari madu bunga melati, ditegaskan kembali 'bunga melati" adalah seseorang yang sangat pengarang puja. Jadi, pengarang saat itu sangat mengidam-idamkan nyidham sari yang berarti anak dari istrinya yang sedang hamil.

\section{Umpomo sliramu [margi wong manis]}

(baris 3/bait 1/kalimat 3)

Di dalam lirik di atas yang merupakan metafora adalah [margi wong manis]. Sebenarnya larik itu adalah pengandaian yang sama seperti dua baris diawal, jika sebelumnya terdapat metafora yang berfungsi sebagai subjek, untuk larik [margi wong manis] merupakan metafora komplementatif. Margi wong manis berarti jalan raya wanita yang manis, maksudnya si pengarang ingin menggambarkan suasana hatinya ingin mengisi hati wanita yang ia puja tersebut, tetapi ia mengibaratkan hati si wanita itu sebagai jalan yang akan ia lalui.

\section{Aku kang bakal [nglewati]}

(baris 4/bait 1/kalimat 4)

Larik di atas yang merupakan metafora adalah [nglewati]. Larik itu adalah kelajutan dari larik sebelumnya. Kata [nglewati] berarti melewati, yang dimaksud pengarang adalah pengarang akan melewati jalan raya wanita yang manis yang berarti pengarang ingin mengisi hati wanita pujaannya itu. Kata [nglewati] termasuk metafora komplementatif karena kedudukannya sebagai komplemen atau pelengkap di dalam kalimat. 
Metafora nominatif ditemukan di dalam bait pertama lagu Nyidham Sari. Selanjutnya, adalah metafora predikatif.

Tansah [kumanthil] ing netro rinoso (baris 7/bait 1/kalimat 5)

Kata [kumanthil] merupakan bentuk predikat yang digunakan untuk disandingkan dan menerangkan sesuatu. Di dalam larik [kumanthil] berarti "terbayang-bayang". Makna yang dimaksud pengarang ialah ketika sedang jatuh cinta, pengarang sampai terbayang-bayang akan keindahan sosok wanita yang ia puja, yakni istrinya. Dilihat dari kalimatnya, yaitu "Tansah kumanthil ing netro rinoso" yang berarti "selalu terbayang-bayang di mata rasanya"

Roso [rasaning] driyo

(baris $8 /$ bait 1/kalimat 5)

Kata [rasaning] merupakan bentuk predikat yang digunakan untuk disandingkan dan menerangkan sesuatu. Dalam larik itu disebutkan Roso rasaning driyo yang berarti "terasa laksana siang hari" yang berarti pengarang menggambarkan jatuh cintanya dia pada seseorang itu hingga terasa sampai siang hari karena ketika ia jatuh cinta pada malam hari, terbukti pada larik sebelumnya terdapat kata "Sineksen lintange luku semono" yang berarti disaksikan bintang pada saat itu (malam hari).

\section{Bait 2}

Mibero sak jagad royo

Kalingono wukir lan samudero

(baris $1 /$ bait $2 /$ kalimat 6 )

Ora ilang memanise (baris $2 /$ bait $2 /$ kalimat 6 )

Dadi ati selawase (baris $3 /$ bait $2 /$ kalimat 6 )

Nalika niro ing dalu atiku

Lamlamun sliro wong ayu

Nganti mati ora bakal lali

La kae lintange mlaku

(baris $4 /$ bait $2 /$ kalimat 6 )

(baris $5 /$ bait $2 /$ kalimat 7 )

(baris 6/bait 2/kalimat 7 )

(baris $7 /$ bait $2 /$ kalimat 7 )

(baris $8 /$ bait $2 /$ kalimat 8 )

Pada bait kedua lagu Nyidham Sari ditemukan ada 2 bentuk metafora. Berikut adalah metafora beserta klasifikasinya.

[Mibero] sak jagad royo

(baris 1/bait 2/kalimat 6)

Dalam arti sebenarnya kata [mibero] berarti 'terbanglah'. Pada metafora [mibero] merupakan bentuk predikat yang digunakan untuk disandingkan dan menerangkan bahwa "berkelilinglah sejagat raya" yang berarti menerangkan dunia (jagat raya). Arti kata 'terbanglah' mengandaikan bahwa sejauh apa pun jarak yang 
memisahkan mereka, ia akan tetap terbayang-bayang pada sesorang yang ia kagumi tersebut. Metafora ini termasuk metafora predikatif.

Lha kae [lintange] mlaku

(baris 8/bait 2/kalimat 8)

Metafora itu termasuk metafora nominatif karena metafora [lintange] berfungsi sebagai subjek kalimat. Kata [lintange] yang berarti "bintang" yang dimaksudkan ini adalah sosok wanita yang sangat ia kagumi. Pengarang mengibaratkan "bintang" itu wanita yang sangat ia kagumi walaupun berjalan di kegelapan "malam hari” ia tetap bercahaya layaknya bintang.

b) Lagu 2 (Yen ing tawang ono lintang)

\section{Bait 1}

Yen ing tawang ono lintang, cah ayu (baris $1 /$ bait $1 /$ kalimat 1 )

Aku ngenteni teka mu

Marang mego ing angkoso (baris 2 /bait $1 /$ kalimat 1 ) (baris $3 /$ bait $1 /$ kalimat 2 )

Sung takok ke pawartamu (baris $4 /$ bait $1 /$ kalimat 2 )

Pada bait pertama lagu Yen Ing Tawang Ono Lintang juga akan dianalisis dan dikategorikan ke dalam bentuk metafora sintaksis. Berikut adalah metafora yang ditemukan dalam bait pertama lagu Yen Ing Tawang Ono Lintang Yen ing tawang ono lintang, [cah ayu] (baris 1/bait 1/kalimat 1)

Baris pertama yang berarti "jika di langit ada bintang, wahai cantik" sebenarnya maksud dari kalimat ini adalah ungkapan sang pengarang ketika menunggu lahirnya anak tercintanya, dia mengibaratkan anaknya yang akan lahir dengan istilah "bintang" dan ia sangat menginginkan anaknya itu adalah anak perempuan karena ia mengibaratkan pada kata "cah ayu”. Metafora ini termasuk metafora nominatif karena metafora terdapat pada subjek kalimat "cah ayu".

\section{Bait 2}

Janji janji aku eleng, cah ayu (baris $1 /$ bait $2 /$ kalimat 3 ) Sumedot roso ing ati Lintang lintang'e wingi wingi nimas (baris $2 /$ bait $2 /$ kalimat 3 ) Tresna ku sundul wiyati Ndek semono janjimu disekseni Mego kartiko keiring roso tresno asih (baris 3/bait $2 /$ kalimat 4 ) (baris $4 /$ bait $2 /$ kalimat 4 ) (baris $5 /$ bait $2 /$ kalimat 5 ) (baris 6/bait 2/kalimat 5) 
Selanjutnya, bentuk metafora pada bait kedua, pada lagu Yen Ing Tawang Ono Lintang ditemukan beberapa metafora, yaitu

Janji janji aku eleng cah ayu

Sumedot roso ing ati (baris $1 /$ bait $2 /$ kalimat 3 )

(baris $2 /$ bait $2 /$ kalimat 3 )

Pada bait kedua ini, akhirnya ditemukan metafora kalimatif, karena baris pertama dan baris kedua adalah kesatuan kalimat. Kalimat [Janji-janji aku eling, cah ayu] yang berarti (setiap saat saya ingat, anak cantik). Maksudnya mengingat situasi di ruang bersalin yang 'menegangkan', yang sudah pernah menunggu istri melahirkan (di luar ruang bersalin), tentu tahu hal ini. Selanjutnya, pada baris kedua [Sumedot roso ing ati] yang berarti (seakan mau ditinggal mati, rasanya di hati). Dalam kalimat ini Sumedot = putus (hubungan dengan seseorang), seperti mau ditinggal pergi jauh, atau ditinggal mati. Maksudnya Andjar Any (pengarang) ini sangat takut dengan keselamatan si jabang bayi yang akan dilahirkan itu.

Mego kartiko [keiring] roso tresno asih

(baris 6/bait 2/kalimat 5)

Metafora [keiring] ini termasuk metafora predikatif karena digunakan untuk disandingkan dan menerangkan kata "Mego Kartiko", yaitu "Awan dan Bintang" yang [keiring] yang berarti "mengiringi". Hal ini maksudnya adalah awan dan bintang mengiringi cinta kasih seorang ayah terhadap anaknya yang begitu besar.

\section{Bait 3}

Yen ing tawang ono lintang, cah ayu (baris 1/bait 3/kalimat 6)

Rungokno tangis ing ati

(baris $2 /$ bait $3 /$ kalimat 6 )

Miraring swara ing ratri nimas

(baris $3 /$ bait $3 /$ kalimat 7 )

Ngenteni bulan ndadari

(baris $4 /$ bait $3 /$ kalimat 7 )

Selanjutnya, bentuk metafora pada bait ketiga pada lagu Yen Ing Tawang Ono Lintang ditemukan beberapa metafora, yaitu

Yen ing tawang ono lintang, [cah ayu]

(baris 1/bait 3/kalimat 6)

Sama seperti bait pertama, baris pertama yang berarti "jika di langit ada bintang, wahai cantik” sebenarnya maksud dari kalimat ini adalah ungkapan sang pengarang ketika menunggu lahirnya anak tercintanya, dia mengibaratkan anaknya yang akan lahir dengan istilah "bintang" dan ia sangat menginginkan anaknya itu adalah anak perempuan karena ia mengibaratkan pada kata "cah ayu”. Metafora disini termasuk metafora nominatif karena metafora terdapat pada subjek kalimat "cah ayu". 
Yang bermetafora adalah kata [tangis ing ati] yang bila diterjemahkan di dalam bahasa Indonesia berarti 'tangisan di hati' yang disebut metafora komplementatif karena kata tersebut berkedudukan sebagai pelengkap.

\section{Analisis Bentuk}

a. Lagu Nyidham Sari

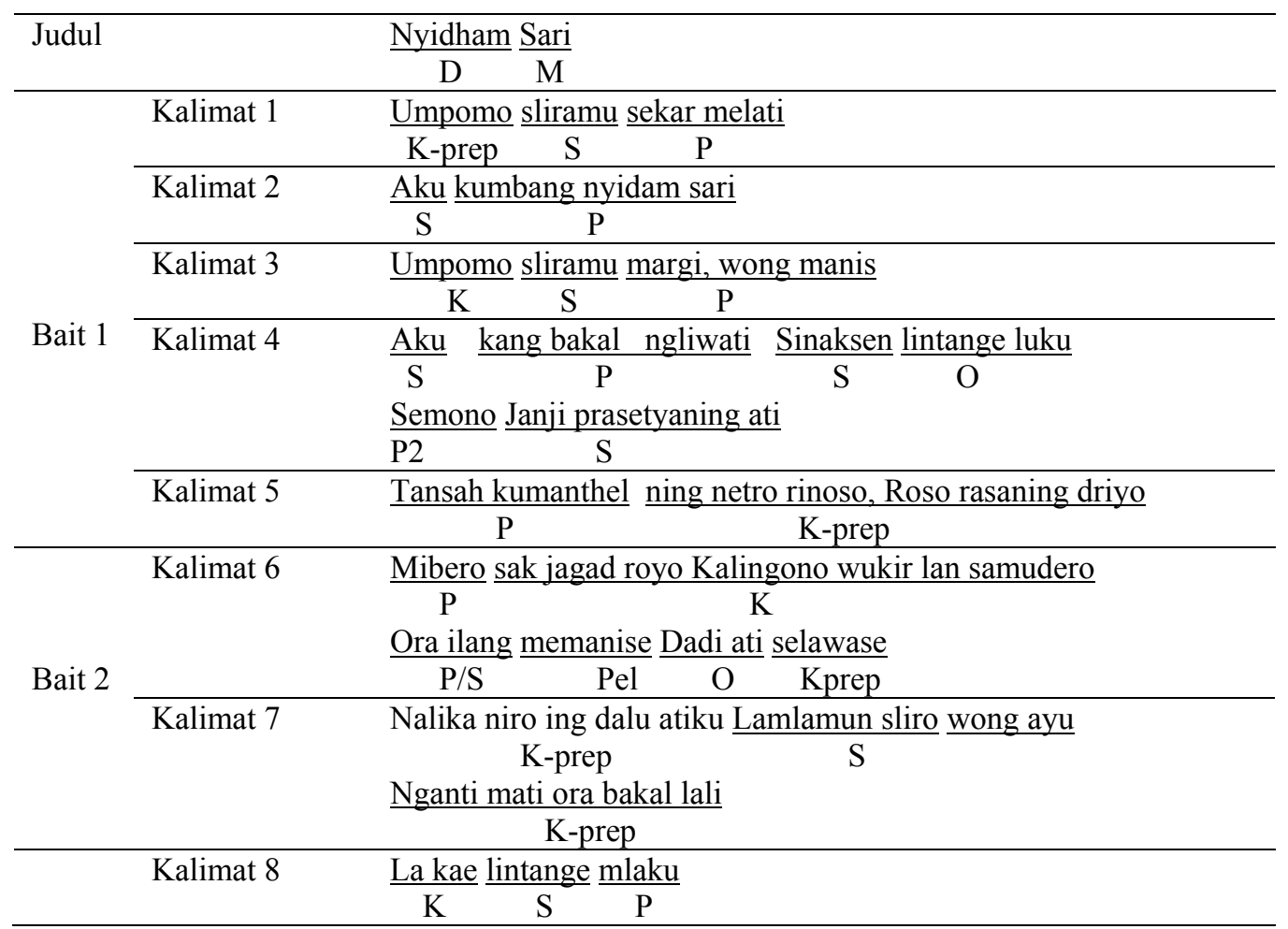

b. Lagu Yen ing tawang ono lintang

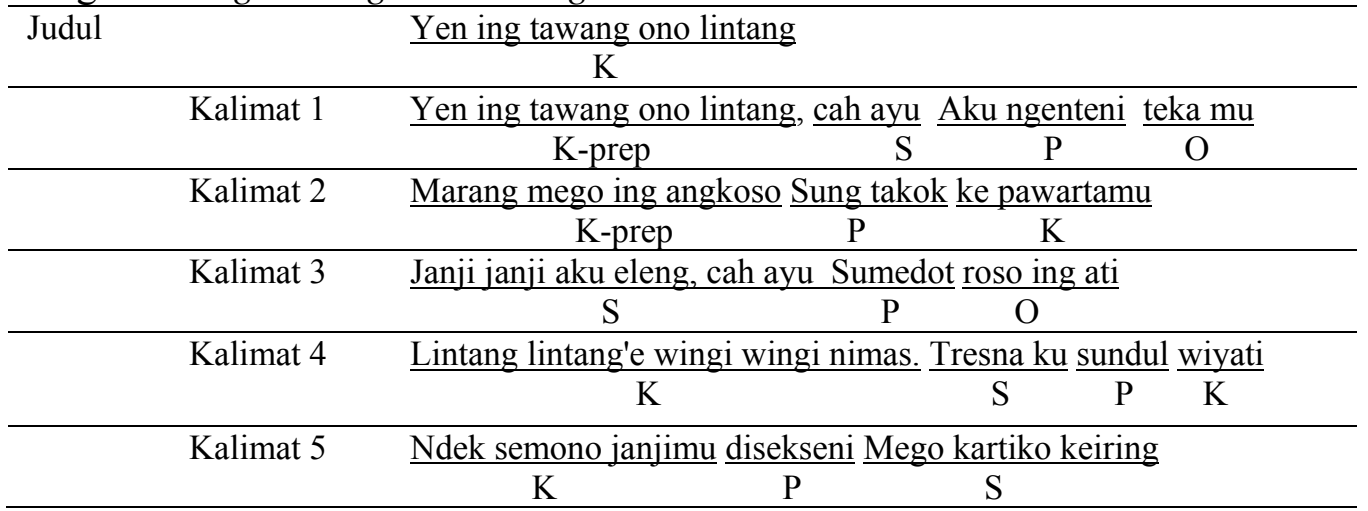




\begin{tabular}{|c|c|}
\hline & $\frac{\text { roso tresno asih }}{\mathrm{O}}$ \\
\hline \multirow[t]{2}{*}{ Kalimat 6} & Yen ing tawang ono lintang cah ayu Rungokno tangis ing ati \\
\hline & K-prep \\
\hline \multirow[t]{2}{*}{ Kalimat 7} & Miraring swara ing ratri nimas Ngenteni bulan ndadari \\
\hline & K-prep \\
\hline
\end{tabular}

\section{Analisis Nomina dan Verba}

a. Lagu Nyidham Sari

\begin{tabular}{|c|c|c|}
\hline \multirow[t]{2}{*}{ Judul } & & Nyidham Sari \\
\hline & & $\mathrm{V} \quad \mathrm{N}$ \\
\hline \multirow{11}{*}{ Bait 1} & Kalimat 1 & Umpomo sliramu sekar melati \\
\hline & & Prep $\mathrm{N} \quad \mathrm{N} \quad \mathrm{N}$ \\
\hline & Kalimat 2 & Aku kumbang nyidam sari \\
\hline & & $\mathrm{V}$ \\
\hline & Kalimat 3 & $\underline{\text { Umpomo sliramu margi, wong manis }}$ \\
\hline & & $\mathrm{N} \quad \mathrm{V}$ \\
\hline & Kalimat 4 & $\begin{array}{cc}\text { Aku } \\
\mathrm{N}\end{array} \frac{\text { kang bakal ngliwati }}{\mathrm{V}} \frac{\text { Sinaksen lintange luku }}{\mathrm{N}}$ \\
\hline & & $\underline{\text { Semono Janji prasetyaning ati }}$ \\
\hline & & $\mathrm{V}$ \\
\hline & Kalimat 5 & Tansah kumanthel ning netro rinoso, Roso rasaning driyo \\
\hline & & $\mathrm{V}$ \\
\hline \multirow{10}{*}{ Bait 2} & Kalimat 6 & Mibero sak jagad royo Kalingono wukir lan samudero \\
\hline & & $\mathrm{V} \quad \mathrm{N}$ \\
\hline & & Ora ilang memanise Dadi ati selawase \\
\hline & & $\begin{array}{llll}\mathrm{V} & \mathrm{N} & \mathrm{V} & \text { Prep } \\
\end{array}$ \\
\hline & Kalimat 7 & $\underline{\text { Nalika niro ing dalu atiku Lamlamun sliro wong ayu }}$ \\
\hline & & Prep \\
\hline & & Nganti mati ora bakal lali \\
\hline & & Prep \\
\hline & Kalimat 8 & $\underline{\text { La kae lintange mlaku }}$ \\
\hline & & $\mathrm{N}$ \\
\hline
\end{tabular}

\section{b. Lagu Yen Ing Tawang Ono Lintang}

\begin{tabular}{|c|c|c|}
\hline \multirow[t]{3}{*}{ Judul } & & $\frac{\text { Yen ing tawang ono lintang }}{\mathrm{K}}$ \\
\hline & \multirow[t]{2}{*}{ Kalimat 1} & 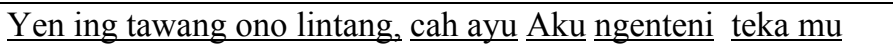 \\
\hline & & Prep \\
\hline & \multirow[t]{2}{*}{ Kalimat 2} & Marang mego ing angkoso Sung takok ke pawartamu \\
\hline & & Prep \\
\hline & \multirow[t]{2}{*}{ Kalimat 3} & 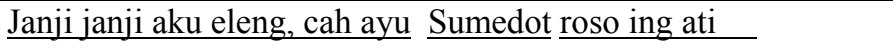 \\
\hline & & $\mathrm{N}$ \\
\hline & \multirow[t]{2}{*}{ Kalimat 4} & 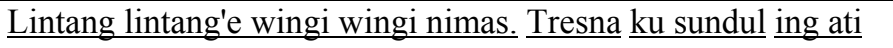 \\
\hline & & $\mathrm{N}$ \\
\hline & \multirow[t]{2}{*}{ Kalimat 5} & Ndek semono janjimu disekseni Mego kartiko keiring roso tresno asih \\
\hline & & $\mathrm{N}$ \\
\hline & \multirow[t]{2}{*}{ Kalimat 6} & 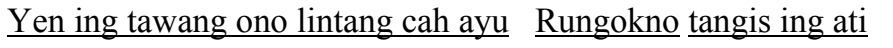 \\
\hline & & $\mathrm{V} \quad \mathrm{N}$ \\
\hline & \multirow[t]{2}{*}{ Kalimat 7} & Miraring swara ing ratri nimas Ngenteni bulan ndadari \\
\hline & & Prep \\
\hline
\end{tabular}


4. Analisis Makna Lagu

a. Lagu Nyidham Sari

\begin{tabular}{|c|c|c|c|c|}
\hline Bait & Kalimat & Baris & Bunyi Larik & Makna \\
\hline \multirow{8}{*}{1} & 1 & 1 & $\begin{array}{l}\text { Umpomo } \\
\text { sliramu sekar } \\
\text { melati }\end{array}$ & $\begin{array}{l}\text { Jadi, kalimat Upama sliramu sekar melati } \\
\text { bermakna 'Umpama dirimu bunga melati' } \\
\text { Pengarang mengibaratkan istrinya sebagai bunga } \\
\text { melati yang harum dan indah. }\end{array}$ \\
\hline & 2 & 2 & $\begin{array}{l}\text { Aku kumbang } \\
\text { nyidham sari }\end{array}$ & $\begin{array}{l}\text { Maksudnya adalah kelanjutan kalimat di atas aku } \\
\text { kumbang nyidham sari, 'aku kumbang yang } \\
\text { sangat mengidam-idamkan sari madumu'. }\end{array}$ \\
\hline & 3 & 3 & $\begin{array}{l}\text { Umpomo } \\
\text { sliramu margi } \\
\text { wong manis }\end{array}$ & $\begin{array}{l}\text { Terjemahan dalam bahasa Indonesia ialah } \\
\text { seandainya dirimu jalan raya wanita yang manis, } \\
\text { maksudnya pengarang mengibaratkan sosok } \\
\text { wanita (istri) yang ia kagumi itu ibarat sebuah } \\
\text { jalan. Kelanjutannya ada di kalimat selanjutnya }\end{array}$ \\
\hline & \multirow[t]{3}{*}{4} & 4 & $\begin{array}{l}\text { Aku kang bakal } \\
\text { ngliwati }\end{array}$ & \multirow{3}{*}{$\begin{array}{l}\text { Yang berarti 'Aku yang akan melewati } \\
\text { disaksikan bintang luku ketika itu janji kesetiaan } \\
\text { hati' yang berarti dia akan sangat bangga } \\
\text { melewati jalan itu dan disaksikan oleh bintang } \\
\text { pada malam hari, yang akan menjadi tanda } \\
\text { kesetiaan hati sang pengarang pada wanita yag } \\
\text { dipuja (istrinya). }\end{array}$} \\
\hline & & 5 & $\begin{array}{l}\text { Sinaksen } \\
\text { lintange luku } \\
\text { semono }\end{array}$ & \\
\hline & & 6 & $\begin{array}{l}\text { Janji } \\
\text { prasetyaning ati }\end{array}$ & \\
\hline & \multirow[t]{2}{*}{5} & 7 & $\begin{array}{l}\text { Tansah } \\
\text { kumanthel ning } \\
\text { netro rinoso }\end{array}$ & \multirow{2}{*}{$\begin{array}{l}\text { Artinya 'Selalu terbayang-bayang di mata } \\
\text { rasanya, terasa laksana siang hari'. Maksudnya } \\
\text { kejadian pada kalimat sebelumnya akan selalu } \\
\text { terbayang-bayang di hatinya meskipun itu terjadi } \\
\text { pada siang hari karena kejadian sebelumnya } \\
\text { berlangsung pada malam hari. Kesimpulannya } \\
\text { akan selalu terkenang sepanjang hari janji } \\
\text { kesetiannya itu }\end{array}$} \\
\hline & & 8 & $\begin{array}{l}\text { Roso rasaning } \\
\text { driyo }\end{array}$ & \\
\hline \multirow{8}{*}{2} & \multirow[t]{4}{*}{6} & 1 & $\begin{array}{l}\text { Mibero sak } \\
\text { jagad royo }\end{array}$ & \multirow{4}{*}{$\begin{array}{l}\text { Artinya, berkelilinglah se jagat raya meski } \\
\text { terhalang gunung dan samudera (lautan), tak akan } \\
\text { hilang wajah manisnya. Jadi, pikiran dalam hati } \\
\text { selamanya, maksud dari kalimat ini adalah ketika } \\
\text { ia mengibaratkan sejauh apa pun istrinya itu } \\
\text { berada walaupun banyak terhalang hal-hal yang } \\
\text { besar tidak akan pernah hilang rasa kagumnya } \\
\text { pada istrinya. }\end{array}$} \\
\hline & & 2 & $\begin{array}{l}\text { Kalingono } \\
\text { wukir lan } \\
\text { samudero }\end{array}$ & \\
\hline & & 3 & $\begin{array}{l}\text { Ora ilang } \\
\text { memanise }\end{array}$ & \\
\hline & & 4 & $\begin{array}{l}\text { Dadi ati } \\
\text { selawase }\end{array}$ & \\
\hline & \multirow[t]{3}{*}{7} & 5 & $\begin{array}{l}\text { Nalika niro ing } \\
\text { dalu atiku }\end{array}$ & \multirow{3}{*}{$\begin{array}{l}\text { Artinya, ketika malam hari, hatiku, selalu } \\
\text { terbayang dirimu wanita cantik. Sampai mati pun } \\
\text { tak akan lupa. Maksud kalimat ini adalah } \\
\text { pengarang bercerita ketika malam hari ia selalu } \\
\text { terbayang wajah istrinya, dan ia menegaskan } \\
\text { bahwa sampai dia mati pun ia tak akan lupa, } \\
\text { begitu ia sangat mencintai istrinya tersebut. }\end{array}$} \\
\hline & & 6 & $\begin{array}{l}\text { Lamlamun sliro } \\
\text { wong ayu }\end{array}$ & \\
\hline & & 7 & $\begin{array}{l}\text { Nganti mati ora } \\
\text { bakal lali }\end{array}$ & \\
\hline & 8 & 8 & $\begin{array}{l}\text { La kae lintange } \\
\text { mlaku }\end{array}$ & $\begin{array}{l}\text { Artinya, ia mengibaratkan istrinya menjadi } \\
\text { bintang di langit yang berjalan karena langit }\end{array}$ \\
\hline
\end{tabular}


selalu terlihat walau kita berada dimana pun.

\section{b. Lagu Yen Ing Tawang Ono Lintang}

\begin{tabular}{ccrl}
\hline Bait & Kalimat & \multicolumn{1}{c}{ Baris } & \multicolumn{1}{c}{ Bunyi Larik } \\
\hline & 1 & 1 & $\begin{array}{l}\text { Yen ing tawang ono } \\
\text { lintang, cah ayu }\end{array}$ \\
\cline { 3 - 4 } & & 2 & Aku ngenteni teka mu \\
\cline { 3 - 4 } & & 3 & $\begin{array}{l}\text { Marang mego ing } \\
\text { angkoso }\end{array}$ \\
\cline { 3 - 4 } & & 4 & $\begin{array}{l}\text { Sung takok ke } \\
\text { pawartamu }\end{array}$ \\
& & 1 & $\begin{array}{l}\text { Janji janji aku eleng, cah } \\
\text { ayu }\end{array}$ \\
\hline & 2 & Sumedot roso ing ati \\
& 3 &
\end{tabular}

Artinya adalah kalau di langit ada
bintang, anak cantik, aku menunggu kedatanganmu. Hal ini menggambarkan pengarang yang sedang menunggu kelahiran anaknya ke dunia.

Artinya, kepada awan di angkasa/langit, Kutanyakan beritamu. Hal ini menggambarkan pengarang bertanya ke angkasa/langit karena dia tidak tahu situasi di ruang bersalin, apa sudah lahir apa belum, bagaimana keadaan sang istri. Artinya, setiap saat saya ingat, anak cantik. Maksudnya mengingat situasi di ruang bersalin yang 'menegangkan' dan (Seakan mau ditinggal mati, rasanya di hati) Sumedot = putus (hubungan dengan seseorang), seperti mau ditinggal pergi jauh, atau ditinggal mati. Maksudnya Sang pengarang ini sangat takut dengan keselamatan si jabang bayi yang akan dilahirkan itu.

\begin{tabular}{lll}
\hline 4 & 3 & $\begin{array}{l}\text { Lintang lintang'e wingi } \\
\text { wingi, nimas }\end{array}$ \\
\cline { 2 - 2 } & 4 & Tresna ku sundul wiyati
\end{tabular}
Artinya, bintang-bintang di langit, sayang. Ni Mas juga artinya mirip dengan sayang, anak manis, dll ( $\mathrm{Ni}=$ wanita, Mas = yang dihormati) Maksudnya bintang akan jadi saksi dan (Cintaku sangat tinggi, sangat dalam) Maksudnya cinta kasih kepada sang anak

\begin{tabular}{ccl}
\hline 5 & 5 & $\begin{array}{l}\text { Ndek semono janjimu } \\
\text { disekseni }\end{array}$ \\
\cline { 2 - 3 } & $6 \begin{array}{l}\text { Mego kartiko keiring } \\
\text { roso tresno asih }\end{array}$ \\
\end{tabular}
Artinya, kala itu, janjiku disaksikan awan dan bintang, teriring rasa cinta dan kasih. Maksud pengarang ingin menegaskan bahwa janji mencintai dengan setulus hati atas apa anugerah yang diberikan Tuhan akan dipegang dan disaksikan awan dan bintang ketika itu.

61 Yen ing tawang ono Artinya, kalau di langit ada bintang, anak lintang cah ayu

2 Rungokno tangis ing ati cantik, dan dengarlah tangisnya hati. Maksud pengarang adalah ingin semuanya mendengar tangisan hati seorang pengarang bahwa ia sangat cemas menunggu hadirnya anak di dunia, ia sangat berharap anak dan istrinya tetap sehat dan bisa berkumpul dengannya lagi.

\begin{tabular}{llll}
\hline 7 & Miraring swara ing ratri & $\begin{array}{l}\text { Artinya, teriring suaranya malam, sayang } \\
\text { nimas }\end{array}$ & dan Ngenteni 'mbulan ndadari -> \\
& 4 mulan dari kata rembulan \\
& ndadari & menanti munculnya rembulan dengan \\
& & bundarnya Maksudnya ialah ketika
\end{tabular}


pengarang benar-benar cemas akan

kelahiran anaknya, ia mengungkapkan bahwa ia ditemani suara malam (suara suasana malam yang sunyi sepi) dan ia juga menanti munculnya rembulan (bulan).

\section{Klasifikasi Metafora}

\section{a. Lagu Nyidham Sari}

\begin{tabular}{|c|c|c|c|c|c|}
\hline \multirow{3}{*}{ Metafora } & \multicolumn{4}{|c|}{ Jenis Metafora } & \multirow{3}{*}{$\begin{array}{l}\text { Keteranga } \\
\mathrm{n}\end{array}$} \\
\hline & \multicolumn{2}{|c|}{ Metafora Nominatif } & \multirow{2}{*}{$\begin{array}{l}\text { Metafora } \\
\text { Predikatif }\end{array}$} & \multirow{2}{*}{$\begin{array}{l}\text { Metafora } \\
\text { Kalimatif }\end{array}$} & \\
\hline & Nominatif & Komplementatif & & & \\
\hline $\begin{array}{l}\text { Umpomo sliramu [sekar } \\
\text { melati] }\end{array}$ & - & $\sqrt{ }$ & - & - & $\begin{array}{l}\text { (baris 1/bait } \\
\text { 1/kalimat l) }\end{array}$ \\
\hline $\begin{array}{l}\text { Aku [kumbang] nyidam } \\
\text { sari }\end{array}$ & $\sqrt{ }$ & I & - & - & $\begin{array}{l}\text { (baris 2/bait } \\
1 / \text { kalimat 2) }\end{array}$ \\
\hline $\begin{array}{l}\text { Umpomo sliramu [margi } \\
\text { wong Metafora }\end{array}$ & \multicolumn{2}{|c|}{ Metafora Nominatif } & Metafora & Metafora & $\begin{array}{l}\text { (baris 3/bait } \\
\text { 1/katninteranga }\end{array}$ \\
\hline Aku kang bakal & Nominatif- & Komplementatif & Predikatif & Kalimatif & (balis 4/bait \\
\hline Umpgmo sfiramu [sekar & - & $\sqrt{ }$ & - & - & (baris 1:bait $_{4}$ ) \\
\hline melatidah [kumanthil] ing & & & $\sqrt{ }$ & & 1/kalimatibait \\
\hline Aku[kumbang] nyidam & $\sqrt{ }$ & - & - & - & (baris zilhait 5 ) \\
\hline sâkoso [rasaning] driyo. & & & $\sqrt{ }$ & & 1/(kalimas 2) \\
\hline Umpomo sliramu [margi & - & $\sqrt{ }$ & - & - & (baris 3/hait 5) \\
\hline wongmanis sak jagad royo & & & $\sqrt{ }$ & & 1/(kalimat B) \\
\hline Aku kang bakal & - & $\sqrt{ }$ & - & - & (barisat/ibait 6 ) \\
\hline Lha kae [lintange] mlaku & $\sqrt{ }$ & - & - & & $\begin{array}{l}\text { (baris } 8 / \text { bait } \\
2 / \text { kalimat } 8 \text { ) }\end{array}$ \\
\hline
\end{tabular}




\begin{tabular}{|c|c|c|c|c|}
\hline [nglewati] & & & & 1/kalimat 4) \\
\hline $\begin{array}{l}\text { Tansah [kumanthil] ing } \\
\text { netro rinoso }\end{array}$ & - & - & $\sqrt{ }$ & $\begin{array}{l}\text { (baris } 7 / \text { bait } \\
1 / \text { kalimat 5) }\end{array}$ \\
\hline Roso [rasaning] driyo & - & - & $\sqrt{ }$ & $\begin{array}{l}\text { (baris } 8 / \text { bait } \\
1 / \text { kalimat 5) }\end{array}$ \\
\hline Mibero] sak jagad royo & - & - & $\sqrt{ }$ & $\begin{array}{l}\text { (baris } 1 / \text { bait } \\
2 / \text { kalimat } 6 \text { ) }\end{array}$ \\
\hline Lha kae [lintange] mlaku & $\sqrt{ }$ & - & - & $\begin{array}{ll} & \text { (baris } 8 / \text { bait } \\
2 / \text { kalimat } 8 \text { ) }\end{array}$ \\
\hline
\end{tabular}

\section{b. Lagu Yen Ing Tawang Ono Lintang}

\begin{tabular}{|c|c|c|c|c|c|}
\hline \multirow{3}{*}{ Metafora } & \multicolumn{4}{|c|}{ Jenis Metafora } & \multirow{3}{*}{ Keterangan } \\
\hline & \multicolumn{2}{|c|}{ Metafora Nominatif } & \multirow{2}{*}{$\begin{array}{l}\text { Metafora } \\
\text { Predikatif }\end{array}$} & \multirow{2}{*}{$\begin{array}{l}\text { Metafora } \\
\text { Kalimatif }\end{array}$} & \\
\hline & Nominatif & Komplementatif & & & \\
\hline $\begin{array}{l}\text { Yen ing tawang ono } \\
\text { lintang, [cah ayu] }\end{array}$ & $\sqrt{ }$ & - & - & - & $\begin{array}{l}\text { (baris } 1 / \text { bait } \\
1 / \text { kalimat } 1 \text { ) }\end{array}$ \\
\hline $\begin{array}{l}\text { Janji janji aku eleng cah } \\
\text { ayu, Sumedot roso ing ati }\end{array}$ & - & - & - & $\sqrt{ }$ & $\begin{array}{l}\text { (baris 1\&2/bait } \\
\text { 2/kalimat 2) }\end{array}$ \\
\hline $\begin{array}{l}\text { Mego kartiko [keiring] } \\
\text { roso tresno asih }\end{array}$ & - & - & $\sqrt{ }$ & - & $\begin{array}{l}\text { (baris 6/bait } \\
\text { 2/kalimat 5) }\end{array}$ \\
\hline $\begin{array}{l}\text { Yen ing tawang ono } \\
\text { lintang, [cah ayu] }\end{array}$ & $\sqrt{ }$ & - & - & - & $\begin{array}{l}\text { (baris } 1 / \text { bait } \\
3 / \text { kalimat } 6 \text { ) }\end{array}$ \\
\hline Rungokno [tangis ing ati] & - & $\sqrt{ }$ & - & - & $\begin{array}{l}\text { (baris } 2 / \text { bait } \\
3 / \text { kalimat 6) }\end{array}$ \\
\hline
\end{tabular}

\section{Rekapitulasi Hipotesis Temuan}

\begin{tabular}{lccllll}
\hline \multicolumn{1}{c}{ Lagu } & $\begin{array}{c}\text { Jumlah } \\
\text { Kata }\end{array}$ & $\begin{array}{c}\text { Jumlah } \\
\text { Bait }\end{array}$ & $\begin{array}{l}\text { Jumlah } \\
\text { Kalimat }\end{array}$ & $\begin{array}{c}\text { Jumlah } \\
\text { Baris/Larik }\end{array}$ & Durasi & \multicolumn{1}{c}{ Jumlah Metafora } \\
\hline $\begin{array}{l}\text { Nyidham } \\
\text { Sari }\end{array}$ & 65 kata & 2 bait & $\begin{array}{l}8 \\
\text { kalimat }\end{array}$ & $\begin{array}{l}16 \\
\text { baris/larik }\end{array}$ & 03.54 & $\begin{array}{l}8 \text { metafora (2 nominatif, 3 } \\
\text { komplementatif, 3 predikatif, } \\
\text { 0 kalimatif) }\end{array}$ \\
\hline $\begin{array}{l}\text { Yen Ing } \\
\text { Tawang Ono } \\
\text { Lintang }\end{array}$ & 66 kata & 3 bait & $\begin{array}{l}7 \\
\text { kalimat }\end{array}$ & $\begin{array}{l}14 \\
\text { baris/larik }\end{array}$ & 04.09 & $\begin{array}{l}5 \text { metafora (2 nominatif, 1 } \\
\text { komplementatif, 1 predikatif, } \\
\text { 1 kalimatif) }\end{array}$ \\
\hline $\begin{array}{l}\text { Jumlah } \\
\text { Keseluruhan }\end{array}$ & 131 kata & 5 bait & $\begin{array}{l}15 \\
\text { kalimat }\end{array}$ & $\begin{array}{l}30 \\
\text { baris/larik }\end{array}$ & 08.03 & $\begin{array}{l}\text { 13 metafora (4 nominatif, 4 } \\
\text { komplementatif, 4 predikatif, } \\
\text { 1 kalimatif) }\end{array}$ \\
\hline
\end{tabular}

\section{PENUTUP}

Berdasarkan hasil penelitian yang sudah dilakukan dapat disimpulkan bahwa makna metafora pada lagu NS dan YITW karya Andjar Any memang sangat terlihat. Hal ini dibuktikan dengan ditemukan 13 metafora, yaitu 4 metafora nominatif, 4 metafora komplementatif, 4 metafora predikatif, dan 1 metafora kalimatif. dalam kedua lagu tersebut, dengan demikian terjawab sudah makna dari beberapa lirik lagu yang sebelumnya kurang bisa dipahami masyarakat awam. 
Lagu ini memang diperuntukkan oleh istri pengarang memang dulu sempat heboh pada zamannya, lagu ini memang banyak disukai oleh banyak orang. Lirik-lirik yang cukup sukar untuk dipahami dan kata-kata yang puitis memang sangat menunjukkan keindahan lagu ini, terlihat dari hasil analisis dari awal sampai akhir menunjukkan kualitas lagu.

\section{DAFTAR PUSTAKA}

Alicia. (2017). Analysis of Metaphors from Rihana's Songs. Journal Language and Culture, 19 (6), 101-117.

Ardiasta. (2013). Karakteristik Lagu Keroncong Karya Kusbini. Yogyakarta: Universitas Negeri Yogyakarta

Any, Andjar. (2007). Kumpulan Lagu Keroncong dan Langgam Jawa Andjar Any. Sukoharjo: Penerbit Cendrawasih

Foriyani. (2013). Karakteristik Pemakaian Bahasa Dalam Tulisan Pada Bodi Bemo Dan Truk Di Surabaya. Ranah; Jurnal Kajian Bahasa, 2 (1), 28-42. https://doi.org.10.26499/rnh.v2i1.53

Kholidah, Umi. (2015). Pemertahanan Bahasa Jawa Pada Interaksi Siswa Dan Guru Dalam Pembelajaran Kajian Sosiolinguistik Di Mts Al-Hikmah Pasir Demak. Ranah; Jurnal Kajian Bahasa, 4 (1), 105-114. https://doi.org.10.26499/rnh.v4i2.27

Liwoso, Margaretha. (2012). Pemahaman Terhadap Metafor Sebagai Sumber Kearifan Masyarakat. Ranah; Jurnal Kajian Bahasa, 1 (2), 11-22. https://doi.org.10.26499/rnh.v1i2.19

Manthous. (2000). Album Manthous CSGK “Nyidham Sari”. Jakarta: Gemas Music Indonesia. Manthous. (2000). Album Manthous CSGK "Yen Ing Tawang Ono Lintang”. Jakarta: Gemas Music Indonesia.

Moeliono, A. M. (2012). "Diksi atau Pilihan Kata". Jakarta: Gramedia.

Moleong. (2010). Metodologi Penelitian Kualitatif. Bandung: PT Remaja Rosdakarya.

Subroto, E. (2011). Pengantar Studi Semantik dan Pragmatik. Surakarta: Cakrawala Media.

Wahab, A. (2010). Isu Linguistik Pengajaran Bahasa dan Sastra. Surabaya: Airlangga University Press. 